\title{
PALMAR DERMATOGLYPHICS IN PATIENTS WITH DIABETES MELLITUS TYPE II AND HYPERTENSION IN THE AGE GROUP OF 35 - 55 YEARS
}

\author{
Sumathi Shekar ${ }^{1}$
}

${ }^{1}$ Assistant Professor, Department of Anatomy, Bangalore Medical College and Research Institute, Bangalore, Karnataka.

\section{ABSTRACT}

\section{BACKGROUND}

Dermatoglyphics is the study of fingertips and palm region. It has been well established as a diagnostic aid in a number of diseases having hereditary basis. Finger print (Dactylography/ Dermatoglyphic) is considered as the best tool of identification.(1) Diabetes mellitus with hypertension is the most important cause of mortality and morbidity in the world. The aetiology of diabetes with hypertension, which is believed to be as a consequence of genetic and environmental factors. Because nothing much can be done prenatally, researchers have resorted to studying physical variables like dermatoglyphics. Dermatoglyphic patterns form on the finger pad and the palm prenatally and remain unchanged throughout life. These features may serve as markers for foetal origin of adult disease like diabetes and hypertension.(2) No studies have been reported on palmar dermatoglyphics in diabetes mellitus type II with hypertension. Palmar dermatoglyphic features derived from qualitative and quantitative parameters in dermatoglyphics of diabetes mellitus type II with hypertension may throw light on foetal origins of an adult disease. Hence, the study has been undertaken.

Aims and Objectives- The present study aims at deriving palmar dermatoglyphic features from quantitative and qualitative parameters in dermatoglyphics of diabetes mellitus type II with hypertension compared to controls.

\section{MATERIALS AND METHODS}

This is a descriptive comparative study. The bilateral rolled finger and palm prints of 100 diabetes with hypertension patients were compared to 100 controls of either sex and age group between 35 - 55 years. Palmar dermatoglyphic features derived from quantitative parameters (TFRC, AFRC, 'a-b' ridge count and a-t-d angles) and qualitative parameters (Fingertip pattern, palmar pattern- interdigital areas, abnormal palmar creases, ridge dissociation, total triradii palm) were analysed.

\section{RESULTS}

Comparisons were made in all parameters between homologous fingers of both hands and also the palm. Analysis was done using mean, standard deviation and z-test. The sample size estimation was also done at conveniences. Statistical analysis of the data of the study showed-1) Increase in frequency of ulnar loops and whorls in both hands of females; 2) Decrease in frequency of whorls in both hands of males; 3) Presence of decreased $\mathrm{I}_{1}$ pattern in the left hand and increased $\mathrm{I}_{3}$ pattern in the left hand of both sexes; 4) Presence of simian line in the left hand of females; 5) Presence of decreased a-b ridge count of females. There was no significant difference in other parameters like TFRC, AFRC, ATD angle, Sydney line, ridge dissociation, total triradii palm between patients and controls.

\section{CONCLUSION}

Overall measures of the dermatoglyphic parameters were prominent features of diabetes and hypertension.

\section{KEY WORDS}

Dermatoglyphics, Diabetes Mellitus Type II, Hypertension, Fingerprints.

HOW TO CITE THIS ARTICLE: Shekar S. Palmar dermatoglyphics in patients with diabetes mellitus type II and hypertension in the age group of 35 - 55 years. J. Evolution Med. Dent. Sci. 2018;7(20):2446-2448, DOI: 10.14260/jemds/2018/550

\section{BACKGROUND}

Dermatoglyphics is a branch of genetics dealing with skin ridge system. The study of epidermal ridges, patterns formed by them in palmar and plantar regions and flexion creases is known as dermatoglyphics. Ridges are genetically determined and influenced by environmental, physical and topographical factors.(3) Dermatoglyphics is a growing discipline and its ease and ready applicability renders it as a useful tool to the clinician.

'Financial or Other Competing Interest': None.

Submission 23-04-2018, Peer Review 05-05-2018,

Acceptance 07-05-2018, Published 14-05-2018.

Corresponding Author:

Dr. Sumathi Shekar,

Department of Anatomy,

Bangalore Medical College and Research Institute,

Bangalore, Karnataka.

E-mail: sumathishekar@gmail.com

DOI: $10.14260 /$ jemds $/ 2018 / 550$

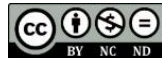

The relevance of dermatoglyphics is not to diagnose but to prevent by predicting a disease; not for defining an existing disease but to identify people with genetic predisposition to develop certain diseases. In the present study, we try to determine significant palmar dermatoglyphic parameters in case of diabetes mellitus type 2 and essential hypertension in the age group between 35 - 55 years. It indicates that there are some genetic factors in the causation of diabetes mellitus type 2 and essential hypertension. Like clinical history, examination and investigations, dermatoglyphics will play an important role in revealing the genetic susceptibility to diabetes mellitus type 2 and essential hypertension.

The term dermatoglyphics (Greek- derma- skin, glyphiccarvings) is the scientific term coined by Anatomist Prof. Harold Cummins of Tulane University in 1926 in the United States (Penrose). The analysis of dermal ridges and their configurations by studying prints of them is called dermatoglyphics. The term is also used as a collective name for all the features of ridged skin. The skin patterns are 
studied from prints and impressions. The study of dermatoglyphics was pioneered long back by Galton in 1892 . The dermal ridge differentiation takes place early in foetal development, evident around $6^{\text {th }}$ week of gestation and reach maximal size by the $12^{\text {th }}$ to $13^{\text {th }}$ week. By the $4^{\text {th }}$ month, the epidermal ridges are nicely developed, but the process is probably not complete before the $6^{\text {th }}$ month of gestation (Alter). Patterns once established never change throughout life. The significance of dermatoglyphic science is based upon two major facts (4)- a) The ridges remain throughout life and survive superficial injury, in other words they are age stable, permanent and also environment stable after $21^{\text {st }}$ week of intrauterine life; b) The ridges are slightly different for each finger and differ from person to person.

\section{MATERIALS AND METHODS}

The study was a descriptive comparative study carried out for over a period of one and a half years from October 2005 to March 2007 with minimum sample of 100 patients. The material for study consisted of patients selected from those attending BLDEA's Shri. B. M. Patil Medical College, Hospital and Research Centre, Bijapur. Patients between age group of 35 - 55 years who were diagnosed as diabetes mellitus type 2 and hypertension were taken for the study by convenient sampling technique. Finger and palm prints of 100 normal persons, i.e. control group were obtained from the outpatient department and staff of Department of Anatomy in the age group between 35 - 55 years. Control group was diagnosed by laboratory tests having (fasting blood sugar $<126 \mathrm{mg} / \mathrm{dL}$, post prandial sugar $<200 \mathrm{mg} / \mathrm{dL}$, fasting and post prandial urine sugars- nil) and recording of blood pressure (s 140/190 mmHg).

Patients were asked to wash both hands with soap and water, so as to remove any oil or dirt. Obtaining of prints was as follows: Black kajal was smeared on both hands one by one and prints were taken by rolling the hands from wrist crease to fingertips on bond paper. The fingers were rolled sideways, so that the whole ridge pattern present on distal aspect of digit (Including the distal interphalangeal crease) was recorded for the palm prints, the person's hand was pressed using even pressure on the dorsum of the hand.

Inclusion and Exclusion Criteria: Patients with deformed finger and palm prints, infection and injuries like burns of fingers and palms, scars of burns of fingers and palms of both hands, patients with type 1 diabetes mellitus, patients with only type 2 diabetes mellitus without hypertension and patients with only hypertension without type 2 diabetes mellitus were excluded from the study.

\section{Statistical Analysis}

The Arithmetic mean and standard deviation were calculated. Z-test was applied. Software used is SPSS 16.0 for statistical analysis.

\section{Significance}

For the value of $\mathrm{Z}$, the critical value of $\mathrm{P}$ is obtained from the normal table for $5 \%$ level of significance.

\section{Parameters}

The quantitative study included mean total finger ridge count (TFRC), mean absolute finger ridge count (AFRC), mean ' $a-b$ ' ridge count and mean 'a-t-d' angles. The qualitative study included fingerprint patterns (arches, radial loops, ulnar loops and whorls) and palmar patterns (Simian line and Sydney line). Statistical analysis was done.

\begin{tabular}{l} 
RESULTS \\
\begin{tabular}{|c|c|c|c|c|c|c|}
\hline Pattern & $\begin{array}{c}\text { Male } \\
\text { Patient }\end{array}$ & $\begin{array}{c}\text { Female } \\
\text { Patient }\end{array}$ & $\begin{array}{c}\text { Male } \\
\text { Control }\end{array}$ & $\begin{array}{c}\text { Female } \\
\text { Control }\end{array}$ & $\begin{array}{c}\text { P } \\
\text { value }\end{array}$ & Inference \\
\hline Arch & 18 & 16 & 14 & 04 & $<0.05$ & S \\
\hline Whorl & 140 & 259 & 262 & 133 & $<0.05$ & S \\
\hline $\begin{array}{c}\text { Radial } \\
\text { loop }\end{array}$ & 05 & 09 & 04 & 11 & $<0.05$ & $\mathrm{~S}$ \\
\hline $\begin{array}{c}\text { Ulnar } \\
\text { loop }\end{array}$ & 237 & 316 & 350 & 222 & $<0.05$ & $\mathrm{~S}$ \\
\hline
\end{tabular} \\
\hline
\end{tabular}

\begin{tabular}{|c|c|c|c|c|c|c|}
\hline & Hand & Patients & Controls & Z-test & P-value & Inference \\
\hline Male & Left & $\begin{array}{c}41.28 \\
(4.92)\end{array}$ & $\begin{array}{c}41.76 \\
(5.93)\end{array}$ & 0.45 & $>=0.77$ & NS \\
\hline \multirow{2}{*}{ Right } & $\begin{array}{c}41.98 \\
(6.44)\end{array}$ & $41.03(5.6)$ & 0.78 & $>=0.43$ & NS \\
\hline Female & Left & $\begin{array}{c}40.60 \\
(4.04)\end{array}$ & $\begin{array}{c}41.75 \\
(5.29)\end{array}$ & 1.14 & $>=0.25$ & NS \\
\hline & Right & $\begin{array}{l}40.38 \\
(3.71)\end{array}$ & $\begin{array}{c}40.73 \\
(4.15)\end{array}$ & 0.42 & $>=0.67$ & NS \\
\hline \multicolumn{7}{|c|}{ Table 2. Mean 'a-t-d' Angle (SD in Brackets) } \\
\hline
\end{tabular}

\begin{tabular}{|c|c|c|c|c|c|}
\hline & Patient & Controls & Z-test & P-value & Inference \\
\hline Male & $\begin{array}{c}121.9 \\
(39.88)\end{array}$ & $\begin{array}{c}134.98 \\
(42.680\end{array}$ & 1.58 & $>=0.1141$ & NS \\
\hline Female & $\begin{array}{c}132.68 \\
(40.83)\end{array}$ & $\begin{array}{c}126.19 \\
(35.1)\end{array}$ & 0.83 & $>=0.4066$ & NS \\
\hline \multicolumn{6}{|c|}{ Table 3. Mean TFRC (SD in Brackets) } \\
\hline
\end{tabular}

\begin{tabular}{|c|c|c|c|c|c|}
\hline & Patient & Control & Z-test & P-value & Inference \\
\hline Male & $\begin{array}{c}157.77 \\
(78.89)\end{array}$ & $\begin{array}{c}186.35 \\
(80.62)\end{array}$ & 1.77 & $>=0.07677$ & NS \\
\hline Female & $\begin{array}{c}181.55 \\
(73)\end{array}$ & $\begin{array}{c}156.13 \\
(62.74)\end{array}$ & 1.79 & $>=0.07$ & NS \\
\hline \multicolumn{6}{|c|}{ Table 4. Mean AFRC (SD in Brackets) } \\
\hline
\end{tabular}

\begin{tabular}{|c|c|c|c|c|c|c|}
\hline & Hands & Patient & Control & Z-test & P-value & Inference \\
\hline Male & Left & $\begin{array}{c}37.42 \\
(5.66)\end{array}$ & $\begin{array}{c}37.55 \\
(5.64)\end{array}$ & Z=0.11 & $>=0.9124$ & NS \\
\hline Right & $\begin{array}{c}35.92 \\
(6)\end{array}$ & $\begin{array}{c}35.68 \\
(5.38)\end{array}$ & Z-0.21 & $>=0.8414$ & NS \\
\hline Female & Left & $\begin{array}{c}37.07 \\
(6.01)\end{array}$ & $\begin{array}{c}40.54 \\
(5.68)\end{array}$ & $\mathrm{Z}=2.99$ & $\mathrm{P}<=0.0028$ & HS \\
\hline \multicolumn{7}{|c|}{ Table 5. Mean 'a-b' Ridge Count } \\
\hline
\end{tabular}

\begin{tabular}{|c|c|c|c|c|}
\hline & Hands & Patient (\%) & Controls (\%) & Inference \\
\hline Male & Left & 1.01 & 0 & NS \\
\hline & Right & 0 & 0 & \\
\hline Female & Left & 0 & 0 & NS \\
\hline & Right & 0 & 0 & \\
\hline \multicolumn{5}{|c|}{ Table 6. Presence of Sydney Line } \\
\hline
\end{tabular}

\begin{tabular}{|c|c|c|c|c|}
\hline & Hands & Patients (\%) & Controls (\%) & Inference (Z-test) \\
\hline Male & Left & $06(6.06)$ & $02(2.02)$ & NS, $\mathrm{P}>0.05$ \\
\hline & Right & $04(4.04)$ & $02(2.02)$ & NS, $\mathrm{P}>0.05$ \\
\hline Female & Left & $12(12.12)$ & $04(4.04)$ & $\mathrm{S}, \mathrm{P}<0.05$ \\
\hline & Right & $04(4.04)$ & $03(3.03)$ & $\mathrm{NS}, \mathrm{P}<0.05$ \\
\hline \multicolumn{5}{|c|}{ Table 7. Presence of Simian Line } \\
\hline
\end{tabular}




\section{DISCUSSION}

Study conducted on diabetes mellitus by Ravindranath and Thomas(4) and also by Verbov(5) showed increase in number of arches. Sant et al(6) showed reduced frequency of radial loops in male diabetics and frequency of ulnar loops reduced in diabetes of both sexes. However, Ravindranath and Thomas found increased radial loops. Verbov and Ravindranath and Thomas found low incidence of whorls, while Sant et al and Ahuja et al(7) found higher incidence of whorls in diabetics.

Study conducted on patients having hypertension by Pursnani et al(8) showed increase in number of arches. According to Jain et al,(9) there was decrease in ulnar loop and Pursnani et al and Godfrey et al showed non-significant difference in ulnar loops on hypertensives. Pursnani et al found higher frequency of whorls. According to Igbigbi et al, whorls were absent in digits of all patients.

In the present study, there were increased ulnar loops and whorls with both hands combined in female patients and decreased whorls with both hands combined in male patients (Table 1).

In studies conducted by Sant et al and Ahuja et al on diabetes found no significant difference. Godfrey et al and Pursnani et al in their study on hypertension observed a decrease in the 'a-t-d' angle.

Verbov, Ahuja et al and Ravindranath and Thomas in their study of non-diabetes mellitus noted an increase in the total finger ridge count. Studies on hypertension by Jain et al and Pursnani et al also showed an increase in TFRC.

Godfrey et al,(10) in their study on hypertension have reported a significant increase in AFRC.

Studies by Ravindranath and Thomas and Ahuja et al on diabetes mellitus showed no significant difference in ' $a-b$ ' ridge count.

In the present study, there was decrease in ' $a-b$ ' ridge count in the left hand of female patients with diabetes mellitus and hypertension as compared to controls (Table 5).

Verbov observed $7.5 \%$ of Sydney line in control male and none in diabetics. In females he noted $11.25 \%$ in control and $2.6 \%$ in diabetics.

Verbov found $2.9 \%$ of diabetic males showed Simian line and $6.25 \%$ showed in control. He also showed $5.3 \%$ presence of Simian line in females and none in control.

In the present study, there was increase in Simian line in the left hand of female patients with diabetes mellitus and hypertension compared to controls (Table 7).
No significant difference was observed in case of either hand, combined or separate in both sexes in a-t-d angle, TFRC, AFRC and Sydney line in the present study (Tables 2, 3, 4 and 6).

\section{CONCLUSION}

Dermatoglyphics, the study of small ridges in palms and soles has proved its importance at least in 3 fields- medicolegal, anthropological and clinical. It is not only a help to the clinicians, but to the cytogeneticists too for resolving the problems in chromosomal identification. This study is also helpful in cases where cytogenetic studies are not possible, e.g. in a pathological specimen, autopsied or aborted materials.

\section{REFERENCES}

[1] Penrose LS. Medical significance of finger-prints and related phenomena. Br Med J 1968;2(5601):321-5.

[2] Penrose LS, Ohara PT. The development of the epidermal ridges. J Med Genet 1973;10(3):201-8.

[3] Alter M. Dermatoglyphic analysis as a diagnostic tool. Medicine (Baltimore) 1967;46(1):35-56.

[4] Ravindranath R, Thomas IM. Finger ridge count and finger print pattern on individual finger in maturity onset diabetes mellitus. J Anat Sciences 1995;14(2):32-6.

[5] Verbov JL. Dermatoglyphics in early-onset diabetes mellitus. Human Hered 1973;23(6):535-42.

[6] Sant SM, Vare AM, Fakruddin S. Dermatoglyphics in diabetes mellitus. J Anat Soc India 1983;32(3):127-30.

[7] Ahuja YR, Iqbal MA, Khubchand J, et al. Dermatoglyphics in diabetes mellitus type 2 Revisted. In: Human biology. Recent advances. New Delhi, India: Today and Tomorrow's Printers and Publishers 1981;2:1-24.

[8] Pursnani ML, Elhence GP, Tibrewala L. Palmar dermatoglyphics in essential hypertension. Indian Heart J 1989;41(2):119-22.

[9] Jain PK, Sharma BK, Mathur BD. Dermatoglyphics in essential hypertension. J Assoc Physicians India 1984;32(4):335-7.

[10] Godfrey KM, Barker DJP, Peace J, et al. Relation of fingerprints pattern and shape of the palm to foetal growth and adult blood pressure. $\mathrm{Br}$ Med J 1993;307(6901):405-9. 